\title{
Thermal-dependent growth characteristics for Cylindrospermopsis raciborskii (Cyanoprokaryota) at different light availabilities: methodological considerations
}

\author{
Attila W. Kovács • Mátyás Présing • Lajos Vörös
}

Received: 23 September 2015/ Accepted: 7 May 2016

(C) Springer Science+Business Media Dordrecht 2016

\begin{abstract}
Cylindrospermopsis raciborskii is one of the most common species of cyanobacteria that can cause nuisance blooms in tropical and subtropical waters. The spatial distribution of this species has become more widespread in temperate regions during the last decade. Sixty combinations of the interaction of light and temperature conditions were examined in this study to elucidate the growth dynamic of $C$. raciborskii ACT 9502 isolated from a temperate shallow lake (Lake Balaton, Hungary). The maximum growth rate of this strain was observed at $32.8^{\circ} \mathrm{C}$ with $164 \mu \mathrm{mol} \mathrm{m}^{-2} \mathrm{~s}^{-1}$ of irradiance. C. raciborskii ACT 9502 was able to grow at both low and high temperatures if the irradiance was low, but could not tolerate the high irradiance at low temperatures. Lowtemperature-induced photoinhibition was observed on higher irradiances with increasing temperature. Results here provide indirect evidence that with global warming, adaptation and high tolerance to a wide range of environmental factors, a harmful cyanobacteria can successfully expand to higher latitudes. The gradient experiment also demonstrated that the
\end{abstract}

Handling Editor: Bas W. Ibelings.

Mátyás Présing: Posthumous author.

A. W. Kovács $(\bowtie) \cdot$ M. Présing · L. Vörös MTA Centre for Ecological Research, Balaton Limnological Institute, Tihany 8237, Hungary

e-mail: kovacswa@gmail.com determination of temperature cardinals of growth and category of high light or shading tolerance significantly depend on the environmental irradiance and temperature. These are important parameters that must be considered when comparing global determinations of growth parameters of this invasive species.

Keywords $\mathrm{N}_{2}$-fixing cyanobacteria $\cdot$ Invasive species - Global warming - Interactive effect of light and temperature $\cdot$ Photoinhibition

\section{Introduction}

Future climatic change scenarios predict rising temperatures (Ciscar et al. 2014), which can provide a catalyst for the global expansion of harmful cyanobacterial blooms (Paerl and Huisman 2008; Jöhnk et al. 2008; Paerl and Paul 2012). Cylindrospermopsis raciborskii is one of the most common toxic species of cyanobacteria that cause nuisance blooms in tropical and subtropical waters (reviewed by Padisák 1997; Antunes et al. 2015), but this species has also been observed in temperate regions of Australia, Africa, Europe, and North and South America in recent years (Druart and Briand 2002; Wood and Stirling 2003; Shaker et al. 2003; Mischke 2003; Bouaïcha and Nasri 2004; Hamilton et al. 2005; Stefaniak and Kokociński 2005; Stüken et al. 2006; Vidal and Kruk 2008; Van Vuuren and Kriel 2008; 
Piccini et al. 2011). In newly invaded waters, $C$. raciborskii can form intense blooms after only a few years of its first appearance, particularly in warmer temperate regions. This negatively impacts the diversity of the natural algal assemblage and outcompetes the native species (Padisák et al. 1984; Chapman and Schelske 1997; Briand et al. 2002; Alster et al. 2010; Kovács et al. 2012).

Knowledge of the optimal and suboptimal conditions for the growth of C. raciborskii is important to better understand the ecology and factors influencing its invasive characteristics. Temperature and light are considered to be the main physical factors that directly control the distribution and productivity of algae. The optimum temperature for the growth of a species is often different from the temperature at which the species can dominate in the field (Eppley 1972; Suzuki and Takahashi 1995; Tang et al. 1997). The dominance of an algal population is not expected to be solely temperature dependent. The effects of temperature or light have been extensively studied independently of each other (temperature effect at a single fixed irradiance and vice versa) (Tilman et al. 1981; Mur 1983; Ahlgren 1987; Thompson et al. 1992; Coesel and Wardenaar 1994; Sosik and Mitchell 1994; Kovács et al. 1997; Malinsky-Rushansky et al. 2002). However, these environmental factors coexist and jointly affect phytoplankton at the species and the community level in the natural environment. Some studies of diatoms, green algae and cyanobacteria demonstrate the importance of the interactions between temperature and light and focus the ecophysiological interest on these environmental factors (Graham et al. 1995; Albertano and Kováčik 1996; Ibelings 1996; Chaneva and Furnadzieva 1997; Popovich and Gayoso 1999; Latała and Misiewicz 2000).

To date, there are no such data available in the literature concerning Cylindrospermopsis raciborskii. Some authors investigated the temperature effect at a single (fixed) irradiance and the influence of irradiance at a single (fixed) temperature for growth of strains of C. raciborskii originating from diverse areas (Shaker et al. 1999; Shafik et al. 2001; Briand et al. 2004, Chonudomkul et al. 2004; Piccini et al. 2011). However, the interaction of the range of light and temperature conditions on the growth of this invasive species is not described. The aim of this research is to fill this knowledge gap and describe the growth rates of $C$. raciborskii across gradients of interaction between temperature and light.

\section{Methods}

Strain, origin and their maintenance

Cylindrospermopsis raciborskii (Wołosz.) Seenayya and Subba Raju (ACT 9502) was isolated from Lake Balaton (Hungary, between $46^{\circ} 62^{\prime}$ and $47^{\circ} 04^{\prime} \mathrm{N}$, and between $17^{\circ} 15^{\prime}$ and $18^{\circ} 10^{\prime} \mathrm{E}$ ) in 1995 . Lake Balaton is the largest shallow lake in central Europe, with a surface area of $596 \mathrm{~km}^{2}$ and mean depth of $3.3 \mathrm{~m}$. As in many temperate and tropical lakes, the eutrophication of Lake Balaton has been associated with an increasing dominance of cyanobacteria. From 1974 to the beginning of the 1990s, the mass development of filamentous cyanobacteria in summer became a regular phenomenon in the western and occasionally in the eastern part of the lake (Gorzó 1985; Vörös and Nagy Göde 1993). The mean annual water temperature of the lake is $12.2{ }^{\circ} \mathrm{C}$. The water temperature is normally above $20{ }^{\circ} \mathrm{C}$ from the end of May to early September, although during hot spells, temperatures of $28{ }^{\circ} \mathrm{C}$ are not unusual. The lake is exposed to strong winds (average $3.2 \mathrm{~m} \mathrm{~s}^{-1}$ over the year), which prevents pronounced thermal stratification. The average value of the light extinction coefficient $\left(K_{\mathrm{d}}\right)$ is $1.78 \mathrm{~m}^{-1}$ in the eastern portion of the lake, ranging from 0.62 to $3.68 \mathrm{~m}^{-1}$. Suspended sediments tend to be the controlling factor for light extinction, which is strongly dependant on wave action. In the more eutrophic western part of the lake, the average $K_{\mathrm{d}}$ value is $3.31 \mathrm{~m}^{-1}$ owing to the abundance of algae, and the transparency is consequently low even in calm weather conditions (Herodek et al. 1988). After 1994, the biomass of algae decreased markedly as a result of implementing a range of management measures to decrease the phosphorous loading (Istvánovics 2008). However, $\mathrm{N}_{2}$-fixing cyanobacteria remained dominant within summer phytoplankton blooms.

The isolated $\mathrm{N}_{2}$-fixing $C$. raciborskii strains were maintained at $21{ }^{\circ} \mathrm{C}$ and $50 \mu \mathrm{mol} \mathrm{m} \mathrm{m}^{-2} \mathrm{~s}^{-1}$ in BG-11 medium (Rippka et al. 1979) with the following modifications: (1) sodium nitrate, the primary nitrogen source, was omitted to avoid morphological deformity, (2) iron (including the ammonium content) and phosphorous concentrations were halved to avoid 
precipitation, and (3) copper content of the medium was decreased to $0.02 \mathrm{mg} \mathrm{l}^{-1}\left(\mathrm{CuSO}_{4} \cdot 5 \mathrm{H}_{2} \mathrm{O}\right)$ because C. raciborskii would not grow within the original $\mathrm{Cu}$ concentrations under isolation process.

\section{Experimental conditions}

C. raciborskii (ACT 9502) subsamples for inoculum were taken from a semi-continuous culture, which was operated at $23{ }^{\circ} \mathrm{C}$ on $80 \mu \mathrm{mol} \mathrm{m}{ }^{-2} \mathrm{~s}^{-1}$. Before starting the growth experiments, each inoculum was preincubated for at least two generations at temperature and irradiance of the treatment. Algae were incubated in autoclaved 500-ml Erlenmeyer flasks containing $150 \mathrm{ml}$ of modified BG11 medium (see above) and plugged with a gauze and cotton stopper. All cultures were mixed at least four times a day. The growth experiments were started at low algal concentration $\left(\mathrm{OD}_{750}=0.009-0.011\right.$, path length of cuvette $10 \mathrm{~mm}$ ) to avoid the self-shading effect. Growth of the $C$. raciborskii treatments was determined in 60 combinations of temperatures $(12,15,18,21,24,27$, $30,33,36$ and $\left.39^{\circ} \mathrm{C}\right)$ and irradiances $(10,30,60,120$, 230 and $390 \mu \mathrm{mol} \mathrm{m}{ }^{-2} \mathrm{~s}^{-1}$ ). The experiments were carried out in a water-filled black sidewall glass aquarium, divided into six compartments by five double-layered black partition walls. These walls included holes at the bottom to ensure the free flow of water for temperature regulation, while avoiding light penetration from adjacent compartments. Continuous illumination was provided from under the aquarium using cool white fluorescent tubes (20 tubes of Tungsram F33, $40 \mathrm{~W}$ ). Irradiance was measured with a LI-190 SB $2 \pi$ Quantum Sensor (LI-COR Inc., USA) in the centre of the bottom of the incubation bottles. To ensure precision of the temperature regulation, a refrigerated bath circulator was used $\left( \pm 0.1{ }^{\circ} \mathrm{C}\right.$, Neslab RTE 210). All treatments were conducted with three replicates.

Determination of growth parameters

Algal growth was monitored by measurement of optical density at $750 \mathrm{~nm}\left(\mathrm{OD}_{750}\right)$ and $650 \mathrm{~nm}$ $\left(\mathrm{OD}_{650}\right)$ at the same time each day using a Shimadzu UV-VIS 160A spectrophotometer (Shimadzu Corporation, Japan). The growth curves determined by $\mathrm{OD}_{750}$ and $\mathrm{OD}_{650}$ were identical, and so specific growth rates of $C$. raciborskii in the cross-gradient experiments were calculated using absorbance at $750 \mathrm{~nm}$. In the preliminary experiments, the growth estimates using optical density were found to be identical to those based on cell biomass determined by microscope counting (Fig. 1; Pearson's correlation coefficient, $r=0.997 ; P<0.001)$.

Maximum specific growth rates $\left(\mu_{\max }^{\prime}\right)$ for individual flasks were calculated for each of the 60 combinations of temperature and irradiance. The relationship between natural $\log \mathrm{OD}_{750}$ and incubation time (day) was plotted, and regression lines were fitted (at least four points) to the linear portion of each curve (Guillard 1973). The slope of the line gave the $\mu_{\max }^{\prime}$ $\left(\right.$ day $\left.^{-1}\right)$ for each flask.

\section{Growth-irradiance relation}

To estimate physiological parameters for the growthirradiance relationship at different temperatures, a photoinhibition model was used as in Platt et al. (1980) with modifications to the photosynthetic rate for growth as in Ojala (1993):

$\begin{aligned} \mu_{\max }^{\prime}= & \mu_{\mathrm{s}} \times\left(1-\exp \left(-\alpha \times E / \mu_{\mathrm{s}}\right)\right) \\ & \times \exp \left(-\beta \times E / \mu_{\mathrm{s}}\right)\end{aligned}$

where $\mu_{\max }^{\prime}\left(\right.$ day $\left.^{-1}\right)$ is the observed maximum specific growth rate for an individual flask at $\mathrm{E}$ irradiance $\left(\mu \mathrm{mol} \mathrm{m} \mathrm{m}^{-2} \mathrm{~s}^{-1}\right) ; \mu_{\mathrm{s}}\left(\right.$ day $\left.^{-1}\right)$ is the theoretical maximum growth rate in the absence of any photoinhibition

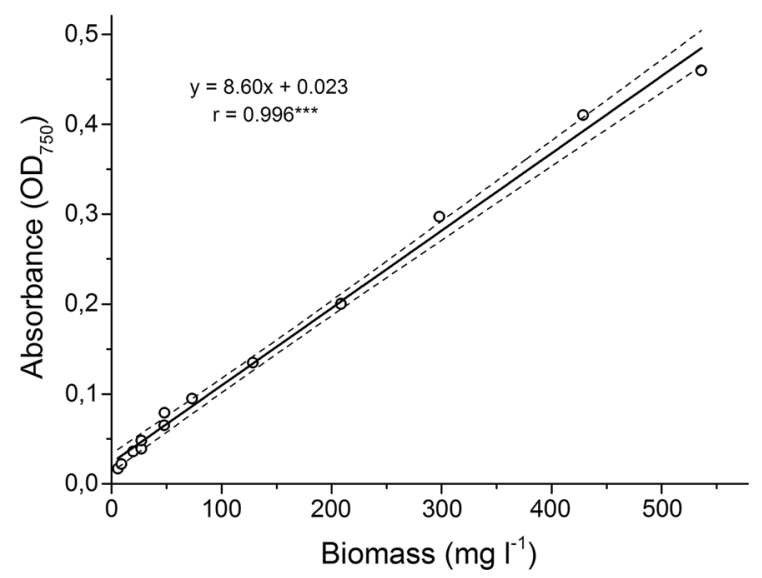

Fig. 1 Correlation between the absorbance measured at $750 \mathrm{~nm}\left(\mathrm{OD}_{750}\right)$ and the biomass of filaments of Cylindrospermopsis raciborskii (ACT 9502). The solid line is the regression through the data, and dashed lines are the $95 \%$ confidence intervals 
at optimal irradiance; $\alpha\left(\right.$ day $\left.^{-1}\left(\mu \mathrm{mol} \mathrm{m} \mathrm{m}^{-2} \mathrm{~s}^{-1}\right)^{-1}\right)$ is the light utilization efficiency for growth (the slope of the linear portion of the curve); $\beta$ is the parameter characterizing photoinhibition.

The maximum growth rate at optimal irradiance $\left(\mu_{\max }\right)$ was calculated from the following equation (Platt et al. 1980):

$\mu_{\max }=\mu_{\mathrm{s}} \times(\alpha /(\alpha+\beta)) \times(\beta /(\alpha+\beta))^{\beta / \alpha}$

The optimal irradiance for growth $\left(\mathrm{E}_{\mathrm{m}(\mu)}, \mu \mathrm{mol} \mathrm{m} \mathrm{m}^{-2}\right.$ $\mathrm{s}^{-1}$ ) where the growth is maximum, the light saturation parameter for growth $\left(\mathrm{E}_{\mathrm{k}(\mu)}, \mu \mathrm{mol} \mathrm{m} \mathrm{m}^{-2} \mathrm{~s}^{-1}\right)$ and the index of photoinhibition susceptibility for growth $\left(\mathrm{E}_{\mathrm{b}(\mu)}, \mu \mathrm{mol} \mathrm{m} \mathrm{s}^{-2}\right)$, respectively, were calculated using the following equations:

$E_{\mathrm{m}(\mu)}=\mu_{\mathrm{s}} /\left(\alpha \log _{\mathrm{e}}((\alpha+\beta / \beta))\right)$, which $\mu_{\max }$ increases with $T$, experimental temperature $\left({ }^{\circ} \mathrm{C}\right)$.

2. Square root model (Ratkowsky et al. 1983):

$$
\begin{aligned}
\sqrt{ } \mu_{\max }= & b \times\left(T-T_{\min }\right) \times(1-\exp (c \times(T \\
& \left.\left.\left.-T_{\max }\right)\right)\right),
\end{aligned}
$$

where $\mu_{\max }\left(\right.$ day $\left.^{-1}\right)$ is the same as in Eq. 6, T (Kelvin, $\mathrm{K})$ is the experimental temperature, $T_{\min }$ and $T_{\max }$ $(\mathrm{K})$ are the minimum and maximum temperatures, respectively, at which the growth rate is zero. The parameter $b$ is the regression coefficient of the square root of growth rate constant versus degrees Kelvin for temperatures below the optimal temperature, whereas $\mathrm{c}$ is an additional constant to enable the model to fit the data for temperatures above the optimal temperature.

3. Cardinal temperature model with inflection, CTMI (Rosso et al. 1993):

$\mu(T)=\mu_{\max } \times \frac{\left(T-T_{\min }\right)^{2} \times\left(T-T_{\max }\right)}{\left(T_{\mathrm{opt}}-T_{\min }\right) \times\left[\left(T_{\mathrm{opt}}-T_{\min }\right) \times\left(T-T_{\mathrm{opt}}\right)-\left(T_{\mathrm{opt}}-T_{\max }\right) \times\left(T_{\mathrm{opt}}+T_{\min }-2 T\right)\right]}$,

$E_{\mathrm{k}(\mu)}=\mu_{\max } / \alpha$,

$E_{\mathrm{b}(\mu)}=\mu_{\mathrm{s}} / \beta$

The parameters $\mu_{\mathrm{s}}, \alpha$ and $\beta$ used in Eqs. 2, 3, 4, 5 are from Eq. 1, and $\mu_{\max }$ is derived from Eq. 2.

\section{Growth-temperature relation}

To estimate physiological parameters for growthtemperature relationships throughout the entire temperature range, three alternative models commonly used by microbiologists were investigated.

1. Parabolic model (Tang et al. 1997):

$\mu_{\mathrm{max}}=\mu_{\mathrm{opt}}-\mu_{\mathrm{opt}}\left(\left(T_{\mathrm{opt}}-T\right)^{2} /(0.5 \times \Delta T)^{2}\right)$,

where $\mu_{\max }\left(\mathrm{day}^{-1}\right)$ is the maximum growth rate at optimal irradiance from the $\mu_{\max }^{\prime}-\mathrm{E}$ curve fitting at each temperature, $\mu_{\mathrm{opt}}\left(\mathrm{day}^{-1}\right)$ is the maximum specific growth rate throughout the entire temperature range, $T_{\mathrm{opt}}\left({ }^{\circ} \mathrm{C}\right)$ is the temperature at which $\mu_{\max }=$ $\mu_{\text {opt }}$, and $\Delta T\left({ }^{\circ} \mathrm{C}\right)$ is the range of temperature over where $\mu_{\max }\left(\right.$ day $\left.^{-1}\right), \mathrm{T}, \mathrm{T}_{\min }$ and $\mathrm{T}_{\max }\left({ }^{\circ} \mathrm{C}\right)$ are the same as in Eq. 7, and $\mathrm{T}_{\mathrm{opt}}\left({ }^{\circ} \mathrm{C}\right)$ is the optimal temperature of growth at which $\mu=\mu_{\max }$.

The activation energy of rate-limiting steps for growth as a function of temperature was determined by employing the logarithmic version of the Arrhenius equation (Kruger and Eloff 1978).

Determination of filament abundance and biovolume

Filaments of $C$. raciborskii were counted by an inverted microscope. A minimum of 400 filaments were counted in each sample, with a typical counting error of $10 \%$ (95\% confidence limits; Lund et al. 1958). The total biovolume of the filaments was calculated from the abundances, and the length and the diameter of filaments were obtained by measuring 30 randomly selected individuals (Hillebrand et al. 1999). The biomass (wet weight) of filaments was estimated from the total volume assuming a specific gravity of 1.0 . 
Statistical analysis

Fitting the Platt model (Platt et al. 1980) to the experimental data $\left(\mu_{\max }-\mathrm{E}\right)$ was done by nonlinear least squares fitting method based on the LevenbergMarquardt algorithm. The data were unweighted. Temperatures at which there was no detectable growth at any irradiances $\left(12\right.$ and $\left.39^{\circ} \mathrm{C}\right)$ were excluded from the curve fitting. The maximum specific growth rates of triplicates grown at different irradiances and temperatures were compared for significance among treatments (light, temperature, their interaction) with a two-way analysis of variance (ANOVA). Significance level was set at $P<0.05$. The Shapiro-Wilk test was performed to assess the normality of maximum growth rates. At the 0.05 level, the data were significantly drawn from a normally distributed population. Pearson's correlation analyses, curve fittings, statistics and graphical plotting were performed using the OriginPro 8.6.0 software package (OriginLab Corporation, USA).

\section{Results}

Temperature dependence of growth of C. raciborskii at optimal light condition

The minimum and maximum temperatures at which growth of $C$. raciborskii strain ACT9502 was observed in the experiments were 12 and $36{ }^{\circ} \mathrm{C}$, respectively. The maximum growth rate was lowest $\left(0.13\right.$ day $^{-1}$ ) at $12{ }^{\circ} \mathrm{C}$ (Fig. 2a), and its values increased with temperature up to $33{ }^{\circ} \mathrm{C}$ where $\mu_{\max }$ $\left(0.81\right.$ day $^{-1}$ ) was observed (Fig. 2c). Above $33^{\circ} \mathrm{C}$, there was an increasing tendency of maximum growth rate turnover, while at $39{ }^{\circ} \mathrm{C}$ the cells did not grow and the inoculum died.

The growth-temperature relationship of $\mathrm{C}$. raciborskii strain ACT9502 showed a linear correlation within two sections of the suboptimal temperature range (Fig. 3a):

(i) at temperatures ranging from 12 to $24{ }^{\circ} \mathrm{C}$ $\left(\mu_{\max }=0.046 \times T-0.428, r=0.994, P<\right.$ $0.001)$;

(ii) at temperatures ranging from 24 to $33^{\circ} \mathrm{C}$ $\left(\mu_{\max }=0.014 \times T+0.335, r=0.980, P<\right.$ $0.01)$.
The inflection point between lines was $24{ }^{\circ} \mathrm{C}$. The activation energy for growth of $C$. raciborskii ACT 9502 as a function of temperature was 71.8 and $16.52 \mathrm{~kJ} \mathrm{~mol}^{-1}$ below and above the inflection point, respectively.

Throughout the entire temperature range, the parabolic function (Eq. 6) did not provide a good fit for the relationship between light-saturated maximum specific growth rates and temperature for $C$. raciborskii ACT 9502 (Fig. 4a). The change in growth with temperature was not symmetrical around $\mathrm{T}_{\text {opt }}$. However, the square root (Eq. 7) and CTMI (Eq. 8) models provided adequate fit for the growth-temperature relationship of this strain (Fig. 4b, c). Fitting showed that the $C$. raciborskii strain 9502 isolated from a temperate lake had a high-temperature optimum for growth $\left(32.8^{\circ} \mathrm{C}\right)$. The $T_{\text {opt }}$ was only a few degrees below the $T_{\max }$, above which no growth occurs. The $T_{\text {mins }}$ of -2.2 and $-3.2{ }^{\circ} \mathrm{C}$ as determined by CTMI and square-root models, respectively, was unrealistically low.

Interaction effect of light and temperature on growth of $C$. raciborskii

The effects of temperature, light and their interaction were significant on the growth of $C$. raciborskii ACT9502 strain (Table 1). The characteristics of growth rate versus irradiance $\left(\mu_{\max }^{\prime}-E\right)$ curves changed markedly with temperature (Fig. 2; Table 2). Three types of $\mu_{\max }^{\prime}-E$ curves were distinguished:

(i) At low temperatures, the light requirement of C. raciborskii was low and photoinhibition of growth appeared with low irradiance (Figs. 2a, 3b). At $12{ }^{\circ} \mathrm{C}$, growth was observed only at the lowest irradiance $\left(10 \mu \mathrm{mol} \mathrm{m} \mathrm{m}^{2} \mathrm{~s}^{-1}\right)$, while the inoculum died at higher irradiances. At $15{ }^{\circ} \mathrm{C}$, growth was observable at every irradiance except $390 \mu \mathrm{mol} \mathrm{m}^{-2} \mathrm{~s}^{-1}$, but was strongly inhibited by light above $30 \mu \mathrm{mol} \mathrm{m} \mathrm{m}^{-2} \mathrm{~s}^{-1}$. With increasing temperature $\left(18,21\right.$ and $\left.24{ }^{\circ} \mathrm{C}\right)$, the photoinhibition of growth appeared at higher irradiances $\left(>60 \mu \mathrm{mol} \mathrm{m} \mathrm{m}^{-2} \mathrm{~s}^{-1}\right.$, $>120 \mu \mathrm{mol} \mathrm{m}{ }^{-2} \mathrm{~s}^{-1},>230 \mu \mathrm{mol} \mathrm{m} \mathrm{m}^{-2} \mathrm{~s}^{-1}$, respectively), and the inhibition effect became weaker. At $24^{\circ} \mathrm{C}$, photoinhibition almost disappeared. 
Fig. 2 Maximum specific growth rates $\left(\mu_{\max }^{\prime}\right)$ of Cylindrospermopsis raciborskii (ACT 9502) as a function of irradiance at 15 , 18,21 and $24{ }^{\circ} \mathrm{C}$ (a), at 27 and $30^{\circ} \mathrm{C}(\mathbf{b})$, at 33 and $36{ }^{\circ} \mathrm{C}(\mathbf{c})$. The lines show the $\mu-E$ curves fitted to the replicates by Platt et al. (1980) model. The fitting statistics are given in Table 1
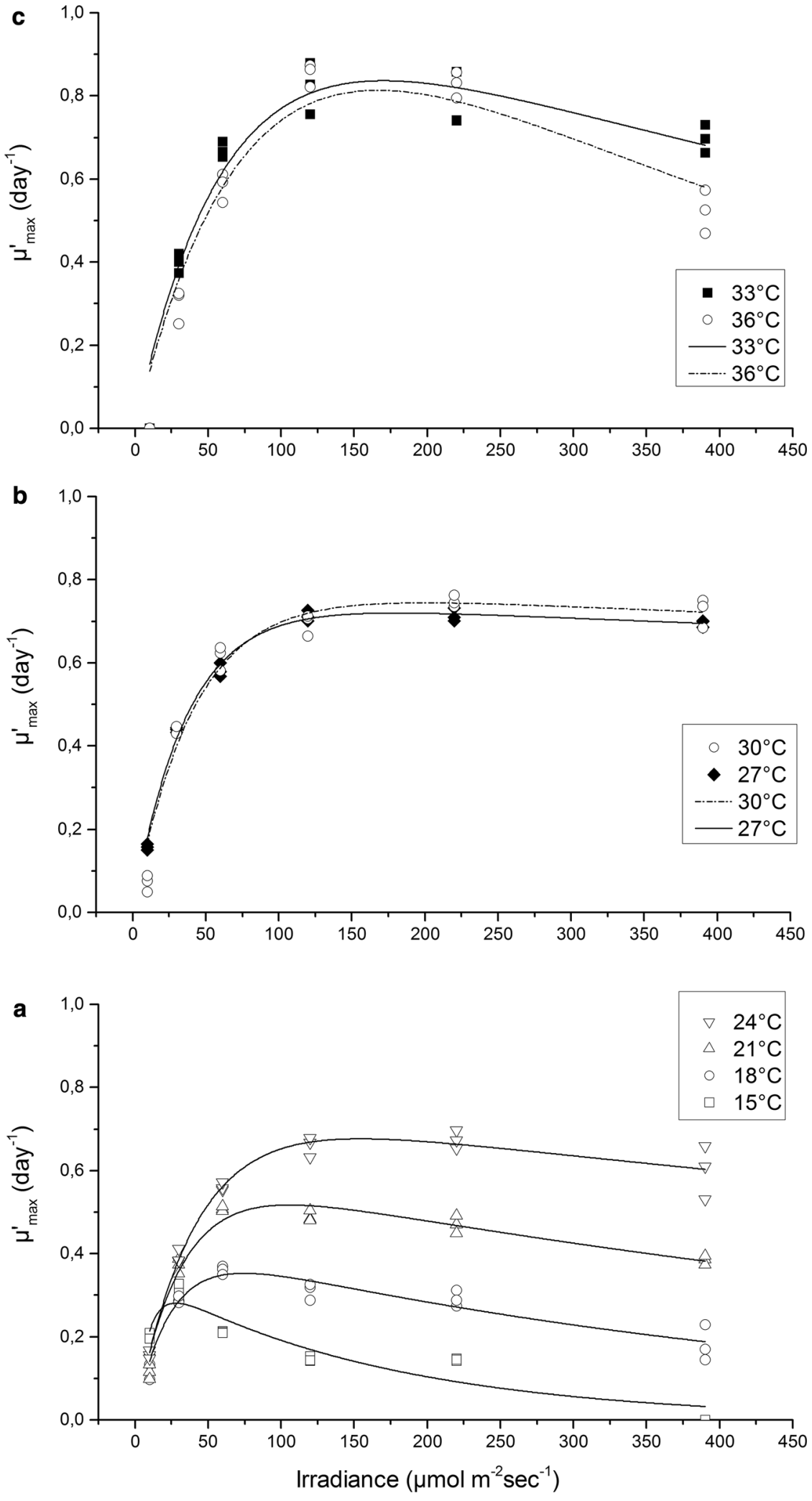

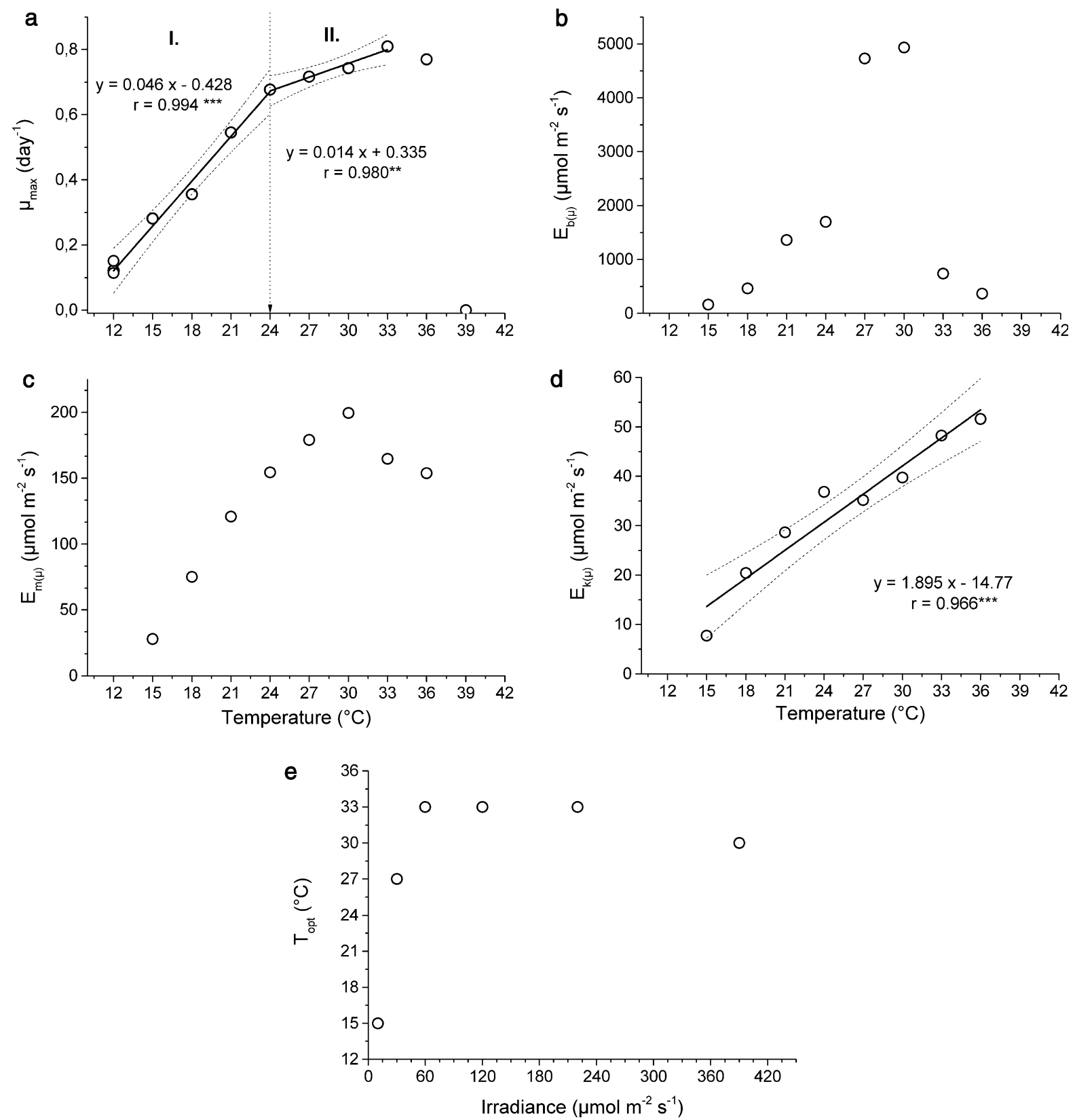

Fig. 3 Estimated physiological parameters for growth-irradiance relationship of Cylindrospermopsis raciborskii (ACT 9502) at different temperatures used by Platt et al. (1980) model; $\mathbf{a} \mu_{\max }$, the maximum growth rate at optimal irradiance at a particular temperature; as a consequence of the impossibility of fitting at $12{ }^{\circ} \mathrm{C}$, each $\mu_{\max }^{\prime}$ value of the triplicate was represented; $\mathbf{b} E_{\mathrm{b}(\mu)}$, the index of photoinhibition susceptibility for growth; $\mathbf{c} E_{\mathrm{m}(\mu)}$, the optimal irradiance for growth; $\mathbf{d} E_{\mathrm{k}(\mu)}$, the light saturation parameter for growth; $\mathbf{e}$ the $T_{\mathrm{opt}}$ for growth of Cylindrospermopsis raciborskii (ACT 9502) at different irradiances

(iii) At high temperatures $\left(33\right.$ and $\left.36{ }^{\circ} \mathrm{C}\right)$, the photoinhibition reappeared above 230 and $120 \mu \mathrm{mol}$ $\mathrm{m}^{-2} \mathrm{~s}^{-1}$, respectively, and became stronger with increasing temperature (Figs. 2c, 3b). 
Fig. 4 Estimated physiological parameters for the growth-temperature relationship of Cylindrospermopsis raciborskii (ACT 9502) by a parabola function model, b cardinal temperature model, c square-root model over the entire temperature range
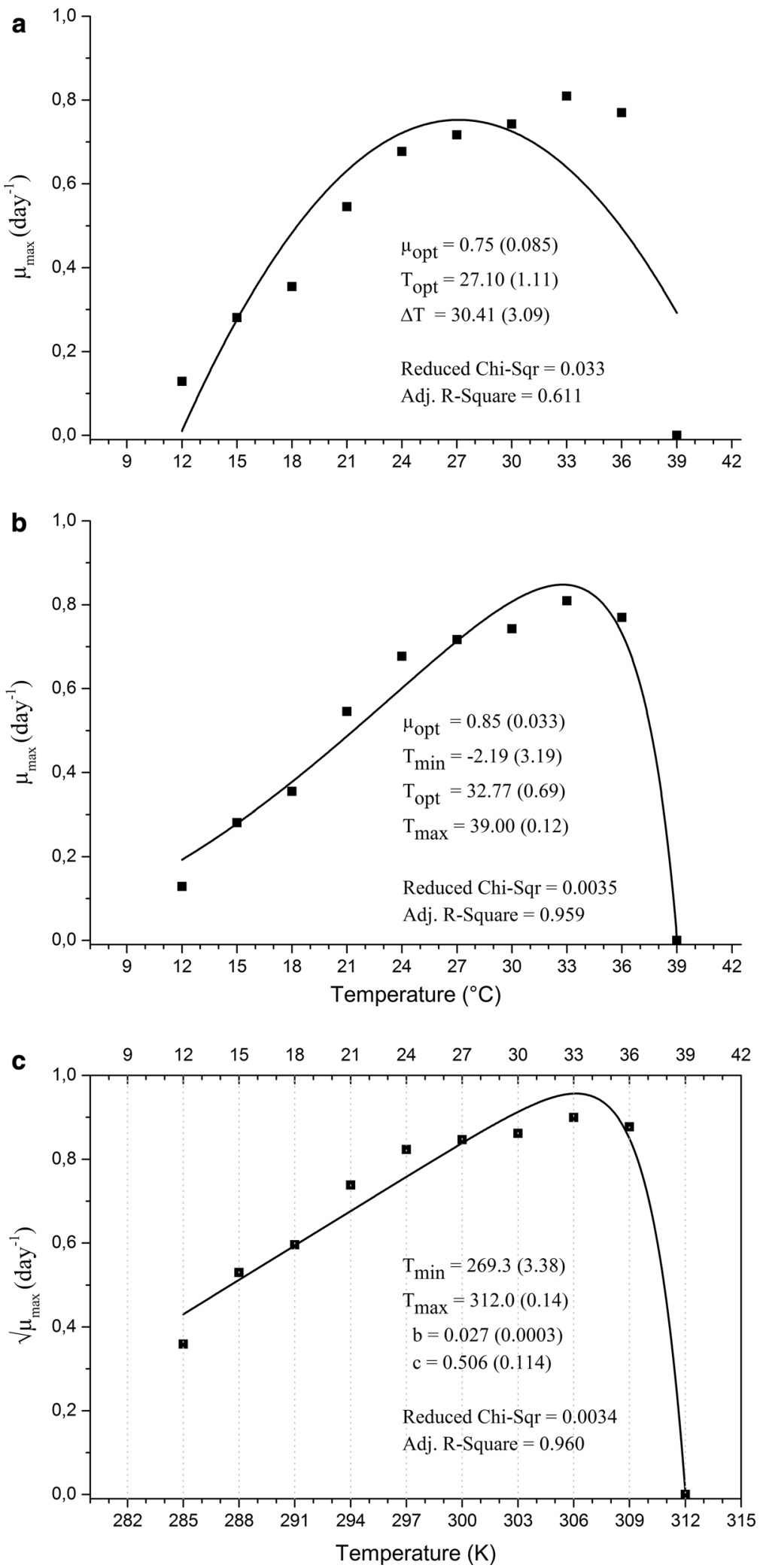
Table 1 Two-way ANOVA for maximum specific growth rate $\left(\mu_{\max }^{\prime}\right)$ of Cylindrospermopsis raciborskii (ACT 9502) as a function of temperature and irradiance

\begin{tabular}{lrllr}
\hline Sources of variation & $d f$ & Ss & Mss & \multicolumn{1}{l}{$F$ values } \\
\hline Temperature & 7 & 2.841 & 0.406 & $560.85^{* * *}$ \\
Irradiance & 5 & 4.045 & 0.809 & $1117.88^{* * * *}$ \\
Interaction & 35 & 2.090 & 0.060 & $82.52^{* * *}$ \\
Model & 47 & 8.976 & 0.191 & $263.90^{* * *}$ \\
Error & 96 & 0.070 & $7.236 \mathrm{E}-4$ & - \\
Corrected total & 143 & 9.045 & - & \multicolumn{1}{l}{-} \\
\hline
\end{tabular}

$D f$ degrees of freedom, $S s$ sum of squares, Mss mean square, $F$ values Fisher $F$ test statistic

*** $P$ value $<0.001$

The photoinhibition property of the $\mu_{\max }-\mathrm{E}$ curve at different temperatures was well quantified by the index of photoinhibition susceptibility $\left(E_{\mathrm{b}(\mu)}\right)$ (Fig. 3b). $E_{\mathrm{b}(\mu)}$ values increased with decreasing photoinhibition from 15 to $27{ }^{\circ} \mathrm{C}$. Above $30{ }^{\circ} \mathrm{C}$, its value decreased parallel with photoinhibition. The optimal irradiance for growth $\left(E_{\mathrm{m}(\mu)}\right)$ of $C$. raciborskii ACT 9502 strain increased with temperature and saturated around 150-200 $\mu \mathrm{mol} \mathrm{m} \mathrm{m}^{-2} \mathrm{~s}^{-1}$ above $24{ }^{\circ} \mathrm{C}$ (Fig. 3c). The light saturation parameter for growth $\left(E_{\mathrm{k}(\mu)}\right)$ was positively correlated with temperature (in the range of $15-36{ }^{\circ} \mathrm{C} ; E_{\mathrm{k}(\mu)}=1.895 \times T-14.77, r=0.966$, $P<0.0001)$ (Fig. 3d). However, the light utilization efficiency $\left(\alpha_{(\mu)}\right)$ showed little change with temperature, with the exception of $15^{\circ} \mathrm{C}$ (Table 2). The $T_{\text {opt }}$ for growth increased sharply at low irradiances and showed a saturated function above $60 \mu \mathrm{mol} \mathrm{m} \mathrm{m}^{-2} \mathrm{~s}^{-1}$ (Fig. 3e).

\section{Discussion}

Temperature dependence of growth at optimal light condition

Population growth is an integrated metabolic parameter, representing the sum of many chemical and physical processes with a strong dependence on temperature. For many phytoplankton species, the relationship between temperature and specific growth rate is either exponential (Eppley 1972; Li and Morris 1982; Thompson et al. 1992) or linear over a relatively large range of temperatures (Rhee and Gotham 1981; Sosik and Mitchell 1994; Montagnes et al. 2003). The square root of $\mu_{\max }$ for C. raciborskii ACT 9502 is linear with temperature in the suboptimal range. However, an abrupt decrease of $\mu_{\max }$ was observed from the optimal temperature to the maximum temperature for growth, as also observed for most bacteria (Ratkowsky et al. 1982; Zwietering et al. 1991). The activation energy for growth of C. raciborskii 9502 under the inflection point is much higher $\left(71.8 \mathrm{~kJ} \mathrm{~mol}^{-1}\right)$ than above $24{ }^{\circ} \mathrm{C}\left(16.52 \mathrm{~kJ} \mathrm{~mol}^{-1}\right)$. In Lake Balaton, C. raciborskii proliferation and blooms were observed generally above $24{ }^{\circ} \mathrm{C}$. Kruger

Table 2 Growth parameters of Cylindrospermopsis raciborskii (ACT 9502) calculated using the Platt et al. (1980) model at different temperatures and a curve-fitting statistic

\begin{tabular}{|c|c|c|c|c|c|c|}
\hline \multirow{2}{*}{$\begin{array}{l}\text { Temperature } \\
\left({ }^{\circ} \mathrm{C}\right)\end{array}$} & \multirow{2}{*}{$\begin{array}{l}\mu_{\mathrm{s}} \\
\left(\text { day }^{-1}\right)\end{array}$} & \multirow{2}{*}{$\begin{array}{l}\alpha \\
\left(\text { day }^{-1}\left(\mu \mathrm{mol} \mathrm{m}{ }^{-2} \mathrm{~s}^{-1}\right)^{-1}\right)\end{array}$} & \multirow{2}{*}{$\begin{array}{l}\beta \\
\left(\text { day }^{-1}\left(\mu \mathrm{mol} \mathrm{m}{ }^{-2} \mathrm{~s}^{-1}\right)^{-1}\right)\end{array}$} & \multicolumn{3}{|l|}{ Fitting statistics } \\
\hline & & & & Reduced Chi-sqr & Adj. $R^{2}$ & $P$ value \\
\hline 15 & $0.354(0.038)$ & $0.0363(0.0073)$ & $0.0022(5.999 \mathrm{E}-4)$ & 0.0014 & 0.490 & $<0.001$ \\
\hline 18 & $0.437(0.030)$ & $0.0174(0.0017)$ & $9.448 \mathrm{E}-4(2.047 \mathrm{E}-4)$ & 0.00074 & 0.895 & $<0.001$ \\
\hline 21 & $0.609(0.035)$ & $0.0190(0.0014)$ & $7.299 \mathrm{E}-4(1.764 \mathrm{E}-4)$ & 0.00092 & 0.951 & $<0.001$ \\
\hline 24 & $0.759(0.037)$ & $0.0184(9.705 \mathrm{E}-4)$ & $4.476 \mathrm{E}-4(1.489 \mathrm{E}-4)$ & 0.00081 & 0.977 & $<0.001$ \\
\hline 27 & $0.752(0.020)$ & $0.0203(6.934 \mathrm{E}-4)$ & $1.533 \mathrm{E}-4(7.461 \mathrm{E}-5)$ & 0.00035 & 0.992 & $<0.001$ \\
\hline 30 & $0.782(0.064)$ & $0.0187(0.0017)$ & $1.581 \mathrm{E}-4(2.283 \mathrm{E}-4)$ & 0.00279 & 0.953 & $<0.001$ \\
\hline 33 & $1.137(0.236)$ & $0.0167(0.0020)$ & $0.00148(0.00102)$ & 0.00708 & 0.919 & $<0.001$ \\
\hline 36 & $1.500(0.000)$ & $0.0150(0.0011)$ & $0.00409(2.7541 \mathrm{E}-4)$ & 0.00699 & 0.926 & $<0.001$ \\
\hline
\end{tabular}

\pm SE for the regression estimate of each parameter is given in parentheses

$\mu_{\mathrm{s}}\left(\mathrm{day}^{-1}\right)$, theoretical maximum growth rate in the absence of any photoinhibition at optimal irradiance; $\alpha$ $\left(\right.$ day $^{-1}\left(\mu \mathrm{mol} \mathrm{m} \mathrm{m}^{-2} \mathrm{~s}^{-1}\right)^{-1}$ ), the light utilization efficiency for growth (the slope of the linear portion of the curve); $\beta$, the parameter characterizing the photoinhibition 
and Eloff (1978) determined that the inflection point of a temperature-growth curve for Microcystis cyanobacteria correlated well with initiation of blooms for this taxon.

Temperature-dependent physiological properties of different algal species have an influence on the community composition of phytoplankton and their geographical distribution. With increasing temperature, the highest growth rates for phytoplankton groups increased from diatoms, via green algae to cyanobacteria (Canale and Vogel 1974; Paerl and Huisman 2009). Our fitting for the entire temperature range shows that the $C$. raciborskii strain 9502 has a high $T_{\mathrm{opt}}$ for growth $\left(32.8^{\circ} \mathrm{C}\right)$. During the largest blooms in Lake Balaton (1982, 1992 and 1994), the summer water temperatures were above $26{ }^{\circ} \mathrm{C}$ and sometime reached $29^{\circ} \mathrm{C}$, and the contribution of $C$. raciborskii to the total phytoplankton biomass was in excess of $90 \%$ (Padisák et al. 1984; Présing et al. 1996). There have been many other reports of $C$. raciborskii blooms and dominance (70-90\% contribution) associated with high water temperatures: Fitzroy river, Australia $27.1-29.5^{\circ} \mathrm{C}$ (Fabbro and Duivenvoorden 1996); local ponds of City Varanasi, India, $28-30{ }^{\circ} \mathrm{C}$ (Singh 1962); Paranoá reservoir, Brazil, 24-28 ${ }^{\circ} \mathrm{C}$ (Branco and Senna 1994); 47 reservoirs and weir pools across tropical and subtropical Queensland, Australia, 28-32 ${ }^{\circ} \mathrm{C}$ (McGregor and Fabbro 2000); and Lake Kinneret, Israel, 29-30 ${ }^{\circ} \mathrm{C}$ (Alster et al. 2010).

Average water temperatures decrease towards higher latitudes in the northern and southern hemispheres of temperate regions, and the expansion of $C$. raciborskii to higher latitudes was observed near the end of the twentieth century (Mischke 2003; Stefaniak and Kokociński 2005; Stüken et al. 2006; Wiedner et al. 2007; Kokociński et al. 2010; Kokociński and Soininen 2012). Generally, this species does not dominate or cause serious blooms in colder temperate regions (the contribution to the algal assemblages is $\sim 10-20 \%$ ). Although Dokulil and Mayer (1996) reported that after $C$. raciborskii was first recorded in a shallow urban lake (Alte Donau, Austria), it quickly became the main algal species, contributing up to $90 \%$ of the total phytoplankton biovolume at $15-18{ }^{\circ} \mathrm{C}$. Our results support other physiological studies (Chonudomkul et al. 2004; Wiedner et al. 2007) that showed the lower limit of $C$. raciborskii growth was $10-12{ }^{\circ} \mathrm{C}$. However, the presence of $C$. raciborskii filaments has been observed below $10{ }^{\circ} \mathrm{C}$ in Lake Balaton in winter (personal communication of E. Takáts and I. Kóbor), when normally $C$. raciborskii overwinters as an akinete in the sediment of this lake (Gorzó 1987; Kovács et al. 2003). Vegetative winter survival of $C$. raciborskii was also observed around this temperature in other regions (Dokulil 2015).

$T_{\text {opt }}$ for growth of cyanobacteria can be significantly higher than the temperature of their native habitats (Tang et al. 1997). Measurements proved that the $T_{\mathrm{opt}}$ for growth of the strains of $C$. raciborskii isolated at different locations in Europe and around the world are between 27.8 and $35^{\circ} \mathrm{C}$ (this study; Chonudomkul et al. 2004; Briand et al. 2004; Mehnert et al. 2010). However, C. raciborskii has a broad tolerance to a range of environmental temperatures, which may explain its ability to spread towards the higher latitudes. The large surveys started for monitoring of lakes (latitude $50^{\circ}-55^{\circ}$ in northern hemisphere) in the last decade verified the presence of $C$. raciborskii more widely than previously thought (Stüken et al. 2006; Kokociński and Soininen 2012). This raises the question as to why northern populations of $C$. raciborskii started to spread north only within the last decades and not earlier? It is worth noting that the exact time this species first entered the susceptible lakes is unknown. The sediment can be seen as a "resting seed bank" in which different types of surviving algal cells accumulate for long periods (even years or decades, Livingstone and Jaworski 1980) until favourable conditions for germination occur in the water. Germination studies have shown that survival cells of "hidden" species (for example, Anabaena compacta and Anabaenopsis cunningtonii in Lake Balaton) exist in the sediment before their vegetative filaments can be observed in the lake water (Padisák and Kovács 1997; Kovács et al. 2012).

Interaction effect of light and temperature on growth of $C$. raciborskii

Numerous data on the specific growth rates of algae in culture have been assembled (Hoogenhout and Amesz 1965; Eppley 1972; Thompson et al. 1992; Suzuki and Takahashi 1995; Shafik et al. 2001; Briand et al. 2004; Piccini et al. 2011). However, the highest growth rates of the studied species were determined only at a single irradiance or temperature. Our results indicate that the growth of $C$. raciborskii at temperatures (which 
principally reflects photosynthesis) depends significantly on the amount of light available. As suggested by Robarts and Zohary (1987), experiments carried out under subsaturating irradiances do not reveal the light-saturated temperature responses and are incomparable with other data. Our results corroborate this conclusion and differ from the results of Briand et al. (2004), who determined the $T_{\mathrm{opt}}$ for growth of ten strains of $C$. raciborskii at low, subsaturating irradiance $\left(30 \mu \mathrm{mol} \mathrm{m} \mathrm{m}^{-2} \mathrm{~s}^{-1}\right)$. Their growth results showed that the optimal temperatures of these strains from tropic and temperate regions were almost the same ( $T_{\text {opt }}$ ranged from 29 to $31{ }^{\circ} \mathrm{C}$, according to the CTMI equation) and did not show any trend concerning geographical origin. However, the authors demonstrated also that differences in light sensitivity among these strains were noticeable. Our results indicate that the relationship between $T_{\text {opt }}$ and irradiance is important for growth $\left(6{ }^{\circ} \mathrm{C}\right.$ difference of $T_{\text {opt }}$ determined at optimal and suboptimal lighting). Presumably, the $T_{\mathrm{opt}}$ of ten $C$. raciborskii strains from tropical and temperate regions would show more characteristic differences if determined at saturating irradiance.

\section{At low temperature, low and high light condition}

Although the initial photochemical reactions are independent of temperature, many associated reactions of photosynthesis are temperature dependent (Raven and Geider 1988). High levels of photosynthetically available radiation have been shown to inhibit photosynthesis (Öquist et al. 1987). It is well established that the susceptibility of photosynthesis to photoinhibition increases at low temperatures; this phenomenon is called low-temperature-induced photoinhibition (Öquist 1983; Long et al. 1994). According to our results, the inhibition irradiances for growth of C. raciborskii were very low (between 12 and $21^{\circ} \mathrm{C}$ ) and with increasing temperature shifted to higher irradiances. This physiological phenomenon should be kept in mind in the planning of experiments and explanation of results. Mehnert et al. (2010) showed that the native cyanobacteria grew at rates of 0.06-0.15 day ${ }^{-1}$, whereas invasive cyanobacteria (including C. raciborskii isolated from Werbellinsee, Germany) did not grow at $10{ }^{\circ} \mathrm{C}$. Lower growth rates for invasive cyanobacteria were also reported compared to native ones (around 0.12 and 0.32 day $^{-1}$ ) at $15^{\circ} \mathrm{C}$, suggesting that the native species were better competitors at low temperatures in some German lakes. However, the authors determined the temperature dependence of growth at a single irradiance $\left(80 \mu \mathrm{mol} \mathrm{m} \mathrm{m}^{-2} \mathrm{~s}^{-1}\right)$. Our results demonstrated that the growth of $C$. raciborskii is strongly dependent on the applied irradiance at low temperatures. At $15^{\circ} \mathrm{C}$, the growth rate of $C$. raciborskii 9502 (0.15-0.2 day $^{-1}$ on $80 \mu \mathrm{mol} \mathrm{m} \mathrm{m}^{-2} \mathrm{~s}^{-1}$ ) coincided very well with values reported for the German strain, but the growth potential was more than $70 \%$ higher $\left(0.32\right.$ day $\left.^{-1}\right)$ measured at lower irradiance $\left(30 \mu \mathrm{mol} \mathrm{m} \mathrm{m}^{-2} \mathrm{~s}^{-1}\right)$.

\section{High temperature and high light condition}

Above $30{ }^{\circ} \mathrm{C}$, the light inhibition for growth of $C$. raciborskii ACT 9502 reoccurred, and the inhibition became stronger with increasing temperature. Ibelings (1996) showed similar results. Irradiances that were sufficient to induce photoinhibition could cause greater damage in Anabaena flos-aquae (cyanobacteria), when combined with increased temperature. In contrast, the results of Jensen and Knutsen (1993) with Spirulina platensis (cyanobacteria) and Wünschmann and Brand's (1992) studies with Synechoccocus sp. (cyanobacteria) showed that photoinhibition decreases with increasing temperature.

\section{High temperature and low light condition}

At high temperatures, the maintenance energy requirement increases parallel with respiration. Graham et al. (1995) reported that the respiratory losses of the filamentous green alga Spirogyra exceeded the photosynthetic carbon incorporation at low irradiances and high temperatures. A similar phenomenon was observed in our experiments. At $30 \mu \mathrm{mol} \mathrm{m} \mathrm{m}^{-2} \mathrm{~s}^{-1}$, the $\mu_{\max }^{\prime}$ of $C$. raciborskii decreased with increasing temperature, while at $10 \mu \mathrm{mol} \mathrm{m}^{-2} \mathrm{~s}^{-1}$ cells died (after inoculation) at both 33 and $36{ }^{\circ} \mathrm{C}$.

According to our results, $C$. raciborskii was able to grow with low irradiance at any temperature (low and high), but could not tolerate high irradiance at low temperatures. This physiological property might explain its seasonal dynamics in nature. In Lake Balaton, the appearance and success of $C$. raciborskii were typical in mid- or late summer when the water temperature was high $\left(22-28^{\circ} \mathrm{C}\right)$ and the available light was relatively low $\left(Z_{\mathrm{m}} / Z_{\mathrm{eu}}>2\right)$. However, in 
contrast to other $\mathrm{N}_{2}$-fixers (Aphanizomenon sp., Anabaena sp.) C. raciborskii was generally absent in late spring or early summer when high irradiance (higher transparency, $Z_{\mathrm{m}} / Z_{\mathrm{eu}}<2$ ) was associated with low temperature. In some years, filaments of $C$. raciborskii appeared in early summer, but proliferated more vigorously in late summer. Apparently, the species-specific temperature dependence of germination contributes to the species succession. The temperature dependence for germination of C. raciborskii showed a unimodal optimum curve with a narrower range of optimum temperatures $\left(22.3-24.0^{\circ} \mathrm{C}\right) \mathrm{com}-$ pared to other $\mathrm{N}_{2}$-fixers (Gorzó 1986; Kovács et al. 2012). However, based on results from Gorzó (1986), it must be noted that the germination of akinetes of $C$. raciborskii can start from $16{ }^{\circ} \mathrm{C}$ and slowly accelerate up to $22.3{ }^{\circ} \mathrm{C}$, where the germination process in time reaches the optimum temperature.

C. raciborskii has been regarded as a superior competitor in the successional pathway of $\mathrm{N}_{2}$-fixers in other lake systems. Pierangelini et al. (2015) showed the capability of $C$. raciborskii NPD to maintain photosynthesis by using the simple and low-cost mechanism of changes in antenna size. This could define its ability to grow and compete with other microalgae in the final stages of HABs, where light is relatively low and stable. These observations suggest that $C$. raciborskii can tolerate self-shading more effectively than other $\mathrm{N}_{2}$-fixing filamentous cyanobacteria. The $I_{\mathrm{k}(\mu)}$ values for growth of C. raciborskii 9502 were very low and showed strong temperature dependence (varied from 7.7 to 52 with increasing temperature). Padisák and Reynolds (1998) proposed a specific assemblage for C. raciborskii ( $\mathrm{Sn}$ ) based on its shade tolerance, which is different from other heterocitic cyanobacteria. In germination experiments with akinetes from fresh sediment of Lake Balaton, Kovács et al. (2012) clearly showed that $C$. raciborskii outcompeted other $\mathrm{N}_{2}$-fixing cyanobacteria at low irradiance $\left(30 \mu \mathrm{mol} \mathrm{m} \mathrm{m}^{-2} \mathrm{~s}^{-1}\right)$, but gradually lose dominance with the increase in light availability. Results from microcosm experiments using isolated strains from German lakes found that the strongest competitors were Aphanizomenon aphanizomenoides, followed by $C$. raciborskii and then other native and invasive $\mathrm{N}_{2}$-fixers (Mehnert et al. 2010). However, the authors noted that the high growth rate of A. aphanizomenoides in the laboratory was contradictory to its low abundance in the field. Mehnert et al. (2010) used a phosphorous-rich complete $\mathrm{Z} 8$ medium for the mesocosm experiment, which may explain the difference in behaviour. In the germination and growth experiments of Kovács et al. (2012), the $\mathrm{N}_{2}$-fixing cyanobacteria showed a very different contribution pattern depending on the initial phosphorous concentration. In the "P-enriched" variant $\left(5600 \mu \mathrm{g} 1^{-1}\right.$ $\left.\mathrm{PO}_{4}-\mathrm{P}\right)$, C. raciborskii was dominant $(47-56 \%$ of the total biovolume) at the beginning of the experiment at the lowest irradiance $\left(30 \mu \mathrm{mol} \mathrm{m}{ }^{-2} \mathrm{~s}^{-1}\right)$, but its contribution to the $\mathrm{N}_{2}$-fixer assemblages decreased to $12 \%$ towards the end of the experiment (15th day). From the 9th day, A. aphanizomenoides became dominant independent of irradiance, in contrast to the results of the phosphorous-poor variant (close to natural condition) where its contribution to the algal assemblage was $<20 \%$.

To explain the spread of $C$. raciborskii to midlatitudes, three different hypotheses have been suggested: (1) high phenotypic plasticity; the species has ability to tolerate a wide range of climatic conditions, (2) global warming; climatic change increases water temperatures and allows species of tropical and subtropical origin to spread to temperate habitats and (3) ecotypes selection; adaptation to variations of habitat and existence of different ecotypes with different fitness. Our results conclude that high physiological tolerance of $C$. raciborskii may enable it to grow in a wide range of environmental conditions. At the same time, the high $T_{\text {opt }}$ for growth of $C$. raciborskii is an advantage with the progressive warming of temperate water bodies. The increase in water temperature, driven by the change in climate, is systematically shifting the start date of germination earlier in the year, resulting in a prolonged proliferation period for $\mathrm{N}_{2}$-fixers and shifting the pelagic population into a phase with higher light intensity (Wiedner et al. 2007). The higher light conditions accelerate germination and provide higher amount of inoculum for planktonic life (Kovács et al. 2012). In line with this, the comparison of our results with the experiments of Mehnert et al. (2010) indicate that the C. raciborskii strain isolated from German lakes can show cold adaptation. The $T_{\text {opt }}$ of the German strain was $4.97{ }^{\circ} \mathrm{C}$ lower than the Hungarian one. This difference was also observed in the water temperature at which $C$. raciborskii appeared in Werbellinsee $\left(17^{\circ} \mathrm{C}\right)$ and in Lake Balaton $\left(21-22^{\circ} \mathrm{C}\right)$. The cold adaptation could indicate that the Hungarian isolate is 
inhibited by light at low temperatures, while the German variant is not.

In conclusion, our results provide indirect evidence that with global warming, adaptation and high tolerance to a wide range of environmental factors, $C$. raciborskii, a harmful cyanobacteria, can successfully expand to higher latitudes. This gradient experiment clearly demonstrates that the determination of the temperature cardinals of growth and category of high light or shading tolerance significantly depend on the environmental irradiance and temperature, respectively. This fact should be kept in mind when comparing global determinations of growth parameters of this invasive species.

Acknowledgments The research was supported by the Balaton Project of the Office of the Prime Minister of Hungary (MEH). The authors would like to particularly acknowledge the late Mátyás Présing, who contributed to this research and was a valued colleague and friend. Constructive comments from reviewers assisted us in manuscript preparation. Thanks are given to Andrew N. Tyler and Caitlin A.L. Riddick for proofreading the English draft of the manuscript.

\section{References}

Ahlgren G (1987) Temperature functions in biology and their application to algal growth constants. Oikos 49:177-190. doi: $10.2307 / 3566025$

Albertano P, Kováčik L (1996) Light and temperature responses of terrestrial sciaphilous strains of Leptolyngbya $\mathrm{sp}$. in cross-gradient cultures. Algol Stud 83:17-28

Alster A, Kaplan-Levy RN, Sukenik A, Zohary T (2010) Morphology and phylogeny of a non-toxic invasive Cylindrospermopsis raciborskii from a Mediterranean Lake. Hydrobiologia 639:115-128. doi:10.1007/s10750-0090044-y

Antunes JT, Leão PN, Vasconcelos VM (2015) Cylindrospermopsis raciborskii: review of the distribution, phylogeography, and ecophysiology of a global invasive species. Front Microbiol 6:1-13. doi:10.3389/fmicb.2015.00473

Bouaïcha N, Nasri A (2004) First report of cyanobacterium Cylindrospermopsis raciborskii from Algerian freshwaters. Environ Toxicol 19:541-543. doi:10.1002/tox.20058

Branco WC, Senna PAC (1994) Factors influencing the development of Cylindrospermopsis raciborskii and Microcystis aeruginosa in the Paranoá Reservoir, Brasília, Brazil. Algol Stud 75:85-96

Briand JF, Robillot C, Quiblier-Llobéras C, Humbert JF, Couté A, Bernard C (2002) Experimental context of Cylindrospermopsis raciborskii (Cyanobacteria) blooms in a shallow pond in France. Water Res 36:3183-3192. doi:10.1016/ S0043-1354(02)00016-7

Briand J-F, Leboulanger C, Humbert J-F, Bernard C, Dufour P (2004) Cylindrospermopsis raciborskii (cyanobacteria) invasion at mid-latitudes: selection, wide physiological tolerance, or global warming? J Phycol 40(2):231-238. doi:10.1111/j.1529-8817.2004.03118.x

Canale RP, Vogel AH (1974) Effects of temperature on phytoplankton growth. J Environ Eng Div 100:229-241

Chaneva G, Furnadzieva S (1997) Influence of temperature and light intensity on the cyanobacterium Plectonema boryanum. Algol Stud 86:137-145

Chapman AD, Schelske CL (1997) Recent appearance of Cylindrospermopsis (Cyanobacteria) in five hypereutrophic Florida lakes. J Phycol 33(2):191-195. doi:10. 1111/j.0022-3646.1997.00191.x

Chonudomkul D, Yongmanitchai W, Theeragool G, Kawachi M, Kasai F, Kaya K, Watanabe MM (2004) Morphology, genetic diversity, temperature tolerance and toxicity of Cylindrospermopsis raciborskii (Nostocales, Cyanobacteria) strains from Thailand and Japan. FEMS Microbiol Ecol 48:345-355. doi:10.1016/j.femsec.2004.02.014

Ciscar JC, Feyen L, Soria A et al (2014) Climate impacts in Europe. The JRC PESETA II project. JRC scientific and politicy reports, EUR 26586EN. doi:10.2791/7409

Coesel PFM, Wardenaar K (1994) Light-limited growth and photosynthetic characteristics of two planktonic desmid species. Freshw Biol 31:221-226. doi:10.1111/j.13652427.1994.tb00856.x

Dokulil MT (2015) Vegetative survival of Cylindrospermopsis raciborskii (Cyanobacteria) at low temperature and low light. Hydrobiologia. doi:10.1007/s10750-015-2228-y

Dokulil MT, Mayer J (1996) Population dynamics and photosynthetic rates of a Cylindrospermopsis-Limnothrix association in a highly eutrophic urban lake, Alte Donau, Vienna, Austria. Algol Stud 83:179-195

Druart JC, Briand JF (2002) First record of Cylindrospermopsis raciborskii (Wołoszyńska) Seenayya et Subba Raju (Cyanobacteria) in a lotic system in France. Ann Limnol 38(4):339-342. doi:10.1051/limn/2002028

Eppley RW (1972) Temperature and phytoplankton growth in the sea. Fish B-NOAA 70:1063-1085

Fabbro LD, Duivenvoorden LJ (1996) Profile of a bloom of the cyanobacterium Cylindrospermopsis raciborskii (Woloszynska) Seenaya and Subba Raju in the Fitzroy River in tropical Central Queensland. Mar Freshw Res 47(5):685-694. doi:10.1071/MF9960685

Gorzó, Gy (1985) A Balaton üledékéből kitenyészthető planktonikus, heterocisztás cianobaktériumok [Planktonic heterocystic cyanobacteria cultivated in the sediment of Lake Balaton.] Hidrol Közlöny 65:357-360. [in Hungarian with English summary]

Gorzó, Gy (1986) A Balaton üledékében előforduló heterocisztás cianobaktérium spórák csírázásának hőfokfüggése. [Temperature dependence germination of akinetes of heterocystic cyanobacteria occurring in the sediment of Lake Balaton]. MHT VI. Országos Vándorgyülés, 499-507. [in Hungarian]

Graham JM, Lembi CA, Adrian HL, Spencer DF (1995) Physiological responses to temperature and irradiance in Spirogyra (Zygnematales, Charophyceae). J Phycol 31:531-540. doi:10.1111/j.1529-8817.1995.tb02546.x

Guillard RRL (1973) Division rates. In: Stein J (ed) Handbook of phycological methods. Culture methods and growth measurements. CUP, Cambridge, pp 289-311 
Gy Gorzó (1987) Fizikai és kémiai faktorok hatása a Balatonban előforduló heterocisztás cianobaktériumok spóráinak csírázására [The influence of physical and chemical factors on the germination of spores of heterocystic cyanobacteria in Lake Balaton.]. Hidrol Közlöny 67:127-133 [in Hungarian with English summary]

Hamilton PB, Ley LM, Dean S, Pick FR (2005) The occurrence of the cyanobacterium Cylindrospermopsis raciborskii in Constance Lake: an exotic cyanoprokaryote new to Canada. Phycologia 44(1):17-25. doi:10.2216/00318884(2005)44[17:TOOTCC]2.0.CO;2

Herodek S, Lackó L, Virág Á (1988) Lake Balaton research and management. Nexus, Budapest

Hillebrand H, Dürselen C-D, Kirschtel D, Pollingher U, Zohary $\mathrm{T}$ (1999) Biovolume calculation for pelagic and benthic microalgae. J Phycol 35:403-424. doi:10.1046/j.15298817.1999.3520403.x

Hoogenhout H, Amesz J (1965) Growth rates of photosynthetic microorganisms in laboratory cultures. Arch Mikrobiol 50:10-25. doi:10.1007/BF00439783

Ibelings AW (1996) Changes in photosynthesis in response to combined irradiance and temperature stress in cyanobacterial surface water blooms. J Phycol 32:549-557. doi:10. 1111/j.0022-3646.1996.00549.x

Istvánovics V (2008) The role of biota in shaping the phosphorus cycle in lakes. Freshw Rev 1:143-174. doi:10.1608/ FRJ-1.2.2

Jensen S, Knutsen G (1993) Influence of light and temperature on photoinhibition of photosynthesis in Spirulina platensis. J Appl Phycol 5:495-504. doi:10.1007/BF02182508

Jöhnk KD, Huisman J, Sharples J, Sommeijer B, Visser PM, Stroom JM (2008) Summer heatwaves promote blooms of harmful cyanobacteria. Glob Change Biol 14:495-512. doi:10.1111/j.1365-2486.2007.01510.x

Kokociński M, Soininen J (2012) Environmental factors related to the occurrence of Cylindrospermopsis raciborskii (Nostocales, Cyanophyta) at the north-eastern limit of its geographical range. Eur J Phycol 47(1):12-21. doi:10. 1080/09670262.2011.645216

Kokociński M, Stefaniak K, Mankiewicz-Boczek J, Izydorczyk K, Soininen J (2010) The ecology of the invasive cyanobacterium Cylindrospermopsis raciborskii (Nostocales, Cyanophyta) in two hypereutrophic lakes dominated by Planktothrix agardhii (Oscillatoriales, Cyanophyta). Eur J Phycol 45:365-374. doi:10.1080/09670262.2010. 492916

Kovács A, Koncz E, Vörös L (1997) Nyári cianobaktérium populációk dominancia viszonyainak alakulása a fényintenzitás függvényében. [Light dependent species succession of heterocystous cyanobacteria]. Hidrol Közlöny 77:14-16 [in Hungarian with English summary]

Kovács WA, Koncz E, Vörös L (2003) Akinete abundance of $\mathrm{N}_{2}$-fixing cyanobacteria in the sediment of Lake Balaton (Hungary). Hydrobiologia 506:181-188. doi:10.1023/B: HYDR.0000008614.76166.28

Kovács WA, Tóth VR, Vörös L (2012) Light-dependent germination and subsequent proliferation of $\mathrm{N}_{2}$-fixing cyanobacteria in a large shallow lake. Ann Limnol Int J Limnol 48(2):177-185. doi:10.1051/limn/2012010

Kruger GHJ, Eloff JN (1978) The effect of temperature on specific growth rate and activation energy of Microcystis and Synechococcus isolates relevant to the onset of natural blooms. J Limnol Soc S Afr 4:9-20. doi:10.1080/ 03779688.1978.9633144

Latała A, Misiewicz S (2000) Effect of light, temperature and salinity on the growth and chlorophyll a content of Baltic cyanobacterium Phormidium amphibium. Arch Hydrobiol 136. Suppl Alg Stud (100):157-180

Li WKW, Morris I (1982) Temperature adaptation in Phaeodactylum tricornutum Bohlin: photosynthetic rate compensation and capacity. J Exp Mar Biol Ecol 58:135-150. doi:10.1016/0022-0981(82)90125-3

Livingstone D, Jaworski GHM (1980) The viability of akinetes of blue-green algae recovered from the sediments of Rostherne Mere. Brit Phycol J 15:357-364. doi:10.1080/ 00071618000650361

Long SP, Humphries S, Falkowski PG (1994) Photoinhibition of photosynthesis in Nature. Annu Rev Plant Physiol Plant Mol Biol 45:633-662. doi:10.1146/annurev.pp.45.060194. 003221

Lund JWG, Kipling C, Le Cren ED (1958) The inverted microscope method of estimating algal numbers and the statistical basis of estimations by counting. Hydrobiologia 11:143-170. doi:10.1007/BF00007865

Malinsky-Rushansky N, Berman T, Berner T, Yacobi YZ, Dubinsky Z (2002) Physiological characteristics of picophytoplankton, isolated from Lake Kinneret: responses to light and temperature. J Plankton Res 24(11):1173-1183. doi:10.1093/plankt/24.11.1173

McGregor BG, Fabbro LD (2000) Dominance of Cylindrospermopsis raciborskii (Nostocales, Cyanoprokaryota) in Queensland tropical and subtropical reservoirs: implications for monitoring and management. Lakes Reserv Res Manag 5:195-205. doi:10.1046/j.1440-1770.2000.00115.x

Mehnert G, Leunert F, Cirés S, Jöhnk KD, Rücker J, Nixdorf B, Wiedner C (2010) Competitiveness of invasive and native cyanobacteria from temperate freshwaters under various light and temperature conditions. J Plankton Res 32:1009-1021. doi:10.1093/plankt/fbq033

Mischke U (2003) Cyanobacteria associations in shallow polytrophic lakes: influence of environmental factors. Acta Oecol 24:S11-S23. doi:10.1016/S1146-609X(03)00003-1

Montagnes DJS, Kimmance SA, Atkinson D (2003) Using $\mathrm{Q}(10)$ : Can growth rates increase linearly with temperature? Aquat Microb Ecol 32(3):307-313. doi:10.3354/ ame032307

Mur LR (1983) Some aspects of the ecophysiology of cyanobacteria. Ann Inst Pastour Mic 134B:61-72. doi:10. 1016/S0769-2609(83)80097-0

Ojala A (1993) Effects of temperature and irradiance on the growth of two freshwater photosynthetic cryptophytes. J Phycol 29(3):278-284. doi:10.1111/j.0022-3646.1993. 00278.x

Öquist G (1983) Effect of low temperature on photosynthesis. Plant Cell Environ 6:281-300. doi:10.1111/1365-3040. ep 11612087

Öquist G, Samuelsson G, Lönneborg A, Gustafson P (1987) Photoinhibition and recovery of photosynthesis in Anacystis nidulans. Acta Chem Scand 41B:108-111. doi:10. 3891/acta.chem.scand.41b-0108

Padisák J (1997) Cylindrospermopsis raciborskii (Woloszynska) Seenayya et Subba Raju, an expanding, highly 
adaptive cyanobacterium: world-wide distribution and review of its ecology. Arch Hydrobiol Suppl Monogr Stud 107:563-593

Padisák J, Kovács A (1997) Anabaena compacta (Nygaard) Hickel—Új kékalga faj a Balaton üledékében és planktonjában [Anabaena compacta (Nygaard) Hickel—a new blue-green algal species in the sediments and plankton of Lake Balaton]. Hidrológiai Közlöny 77:29-32 [in Hungarian with English summary]

Padisák J, Reynolds CS (1998) Selection of phytoplankton associations in Lake Balaton, Hungary, in response to eutrophication and restoration measures, with special reference to the cyanoprokaryotes. Hydrobiologia 384:41-53. doi:10.1023/A:1003255529403

Padisák J, G-Tóth L, Vörös L (1984) Anabaenopsis raciborskii Wolosz. bloom in lake Balaton in the summer and autumn of 1982. BFB-Bericht 51:77-81

Paerl HW, Huisman J (2008) Blooms like it hot. Science 320:57-58. doi:10.1126/science. 1155398

Paerl HW, Huisman J (2009) Climate change: a catalyst for global expansion of harmful cyanobacterial blooms. Environ Microbiol Rep 1:27-37. doi:10.1111/j.1758-2229. 2008.00004.x

Paerl HW, Paul VJ (2012) Climate change: links to global expansion of harmful cyanobacteria. Water Res 46:1349-1363. doi:10.1016/j.watres.2011.08.002

Piccini C, Aubriot L, Fabre A, Amaral V, González-Piana M, Gianni A, Figueredo CC, Vidal L, Kruk C, Bonilla S (2011) Genetic and eco-physiological differences of South American Cylindrospermopsis raciborskii isolates support the hypothesis of multiple ecotypes. Harmful Algae 10:644-653. doi:10.1016/j.hal.2011.04.016

Pierangelini M, Stojkovic S, Orr PT, Beardall J (2015) Photoacclimation to low light-changes from growth to antenna size in the cyanobacterium Cylindrospermopsis raciborskii. Harmful algae 46:11-17. doi:10.1016/j.hal.2015. 04.004

Platt T, Gallegos CL, Harrison WG (1980) Photoinhibition of photosynthesis in natural assemblages of marine phytoplankton. J Mar Res 38:687-701

Popovich CA, Gayoso AM (1999) Effect of irradiance and temperature on the growth rate of Thalassiosira curviseriata Takano (Bacillarophyceae), a bloom diatom in Bahía Blanca estuary (Argentina). J Plankton Res 21(6):1101-1110. doi:10.1093/plankt/21.6.1101

Présing M, Herodek S, Vörös L, Kóbor I (1996) Nitrogen fixation, ammonium and nitrate uptake during a bloom of Cylindrospermopsis raciborskii in Lake Balaton. Arch Hydrobiol 136(4):553-562

Ratkowsky DA, Olley J, McMeekin TA, Ball A (1982) Relation between temperature and growth rate of bacterial cultures. J Bacteriol 149(1):1-5

Ratkowsky DA, Lowry RK, McMeekin TA, Stokes AN, Chandler RE (1983) Model for bacterial culture growth rate throughout the entire biokinetic temperature range. J Bacteriol 154(3):1222-1226

Raven JA, Geider RJ (1988) Temperature and algal growth. New Phytol 110:441-461

Rhee G-Y, Gotham IJ (1981) The effect of environmental factors on phytoplankton growth: temperature and the interactions of temperature with nutrient limitation. Limnol Oceanogr 26:635-638. doi:10.4319/lo.1981.26.4.0635

Rippka R, Deruelles J, Waterbury JB, Herdman M, Stainer RY (1979) Generic assignments, strain histories and properties of pure cultures of cyanobacteria. J Gen Microbiol 111:1-61. doi:10.1099/00221287-111-1-1

Robarts RD, Zohary T (1987) Temperature effects on photosynthetic capacity, respiration, and growth rates of bloomforming cyanobacteria. N Z J Mar Fresh Res 21:391-399. doi:10.1080/00288330.1987.9516235

Rosso L, Lobry JR, Flanrois JP (1993) An unexpected correlation between Cardinal temperatures of microbial growth highlighted by a new model. J Theor Biol 162:447-463. doi:10.1006/jtbi.1993.1099

Shafik HM, Herodek S, Présing M, Vörös L (2001) Factors effecting growth and cell composition of cyanoprokaryote Cylindrospermopsis raciborskii (Wołoszyńska) Seenayya et Subba Raju. Arch Hydrobiol Suppl Algol Stud 103:75-93

Shaker LM, Neilan BA, Griffiths DJ (1999) Two morphological forms of Cylindrospermopsis raciborskii (Cyanobacteria) isolated from Solomon dam, Palm Island, Queensland. J Phycol 35:599-606. doi:10.1046/j.1529-8817.1999. 3530599.x

Shaker ML, Nogueira ICG, Vasconcelos VM (2003) First report and toxicological assessment of the cyanobacterium Cylindrospermopsis raciborskii from Portuguese freshwaters. Ecotoxicol Environ Saf 55:243-250. doi:10.1016/ S0147-6513(02)00043-X

Singh NR (1962) Seasonal variants of Anabaenopsis Raciborskii Wolosz. Hydrobiologia 20:87-91. doi:10.1007/ BF00038737

Sosik MH, Mitchell BG (1994) Effects of temperature on growth, light absorption, and quantum yield in Dunaliella tertiolecta (Chlorophyceae). J Phycol 30:833-840. doi:10. 1111/j.0022-3646.1994.00833.x

Stefaniak K, Kokociński M (2005) Occurrence of invasive Cyanobacteria species in polimictic lakes of the Wielkopolska Region (Western Poland). Oceanol Hydrobiol Stud 34(Suppl. 3):137-148

Stüken A, Rücker J, Endrulat T, Preussel K, Hemm M, Nixdorf B, Karsten U, Wiedner C (2006) Distribution of three alien cyanobacterial species (Nostocales) in northeast Germany: Cylindrospermopsis raciborskii, Anabaena bergii and Aphanizomenon aphanizomenoides. Phycologia 45(6):696-703. doi:10.2216/05-58.1

Suzuki Y, Takahashi T (1995) Growth responses of several diatom species isolated from varies environments to temperature. J Phycol 31:880-888. doi:10.1111/j.0022-3646. 1995.00880.x

Tang EPY, Tremblay R, Vincent WF (1997) Cyanobacterial dominance of polar freshwater ecosystems: are high-latitude mat-formers adapted to low temperature? J Phycol 33:171-181. doi:10.1111/j.0022-3646.1997.00171.x

Thompson AP, Guo M-X, Harrison PJ (1992) Effect of variation in temperature. I. On the biochemical composition of eight species of marine phytoplankton. J Phycol 28:481-488. doi:10.1111/j.0022-3646.1992.00481.x

Tilman D, Mattson M, Langer S (1981) Competition and nutrient kinetics along a temperature gradient: an experimental test of a mechanistic approach to niche theory. 
Limnol Oceanogr 26:1020-1033. doi:10.4319/lo.1981.26. 6.1020

Van Vuuren SJ, Kriel GP (2008) Cylindrospermopsis raciborskii, a toxic invasive cyanobacterium in South African fresh waters. Afr J Aquat Sci 33(1):17-26. doi:10.2989/ AJAS.2007.33.1.2.386

Vidal L, Kruk C (2008) Cylindrospermopsis raciborskii (Cyanobacteria) extends its distribution to Latitude $34^{\circ} 53^{\prime} \mathrm{S}$ : taxonomical and ecological features in Uruguayan eutrophic lakes. PANAMJAS 3(2):142-151

Vörös L, Nagy Göde P (1993) Long term changes of phytoplankton in Lake Balaton (Hungary). Verh Int Verein Limnol 25:682-686

Wiedner C, Rücker J, Brüggemann R, Nixdorf B (2007) Climate change affects timing and size of population of an invasive cyanobacterium in temperate regions. Oecologia 152:473-484. doi:10.1007/s00442-007-0683-5

Wood SA, Stirling DJ (2003) First identification of the cylindrospermopsin-producing cyanobacterium Cylindrospermopsis raciborskii in New Zealand. N Z J Mar Fresh Res 37:821-828. doi:10.1080/00288330.2003.9517211

Wünschmann G, Brand II (1992) Rapid turnover of a component required for photosynthesis explains temperature dependence and kinetics of photoinhibition in a cyanobacterium, Synechococcus 6301. Planta (Berl.) 186:426-433. doi:10. 1007/BF00195324

Zwietering MH, de Koos JT, Hasenack BE, de Wit JC, van't Riet K (1991) Modeling of bacterial growth as a function of temperature. Appl Environ Microbiol 57(4):1094-1101 